\title{
TRANSFORMATION OF YEAST WITHOUT THE USE OF FOREIGN DNA
}

\author{
by \\ MORTEN C. KIELLAND-BRANDT, TORSTEN NILSSON-TILLGREN।, \\ STEEN HOLMBERG, JENS G. LITSKE PETERSEN and BO A. SVENNINGSEN \\ Department of Physiology, Carlsberg Laboratory, \\ Gamle Carlsberg Vej 10, DK-2500 Copenhagen Valby \\ and \\ I Institute of Genetics, University of Copenhagen, \\ Oster Farimagsgade 2A, DK-1353 Copenhagen K
}

Keywords: Saccharomyces cerevisiae, yeast plasmid, 2-micron DNA, histidine, HIS4 gene, deletions

Isolated circular molecules of the yeast plasmid 2-micron DNA were converted to linear molecules with restriction endonuclease Pstl and ligated with T4 DNA ligase to Pstl restriction fragments of total yeast DNA. A haploid strain of Saccharomyces cerevisiae carrying a deletion in the his 4 locus was transformed with the ligated DNA mixture to histidine prototrophy. One unstable histidine prototrophic transformant was obtained. Grown in the absence of histidine, 70-75\% of the cells were auxotrophic and this number increased in non-selective medium. The histidine auxotrophic variants carried a deletion in the his 4 locus which had patterns of complementation and UV-induced mitotic recombination identical to the original his 4 deletion. When the transformant was crossed to a his 4 strain and sporulated, the unstable histidine prototrophy segregated in a nonmendelian way: All five possible segregations from 0:4 to 4:0 were observed. When strains carrying the transformed character were crossed to a his 4 karl strain a low frequency of cytoduction of the unstable histidine prototrophy was observed. Nucleic acid from the transformant was able to transform a strain which carried another deletion in the his 4 locus. Treatment of the transformant with ethidium bromide caused an extensive induction of petites without any observable change in the frequency of histidine prototrophic cells.

It is concluded that the HIS4 gene function in the transformant is not stably associated with any chromosome. We take the instability as indication that only one or a few copies of the gene conferring the prototrophy are present in the prototrophic cells. The data are consistent with the assumption that the transformant contains a 2micron DNA in which is inserted a chromosomal DNA region containing the HIS4 gene. A derivative of the transformant with increased stability has been isolated. 


\section{INTRODUCTION}

Genetic transformation in Saccharomyces cerevisiae has been convincingly demonstrated by HiNNEN et al. (11) and BegGs (1). In both studies spheroplasts of leucine requiring (leu2) yeast strains were transformed to leucine prototrophy with bacterial plasmid preparations in which all molecules carried the yeast $L E U 2$ gene. These chimaeric plasmids had been constructed in vitro and selected and propagated in Escherichia coli on the basis of the ability of the yeast $L E U 2$ gene to complement the E. coli leuB gene (18). Since most of the yeast transformants carried not only the LEU2 gene, but also the bacterial plasmid as a new part of their genome, molecular hybridization with radioactive plasmid DNA was a helpful technique for their characterization. The transformation frequency of $10^{4-10^{5}}$ transformants per $\mu \mathrm{g}$ of DNA obtained by BEGGS (1) suggests that the selection and propagation of the yeast genetic material in E. coli are dispensable for transformation.

It would be of interest to have a yeast transformation vector system without the involvement of foreign DNA. Like the study of BEGGs (1) our attempts to develop such a system are based on the use of 2-micron DNA, which is a naturally occurring circular plasmid in $\mathrm{S}$. cerevisiae (20). We ligated a mixture of restriction endonuclease fragments of total yeast DNA to linear pieces of 2-micron DNA and used the ligated mixture to transform a histidine auxotrophic yeast strain to histidine prototrophy. The ligated mixture contained a very low concentration of any given chromosomal gene and was therefore expected to give a lower transformation frequency than the preselected DNA preparations used by HinNen et al. (11) and BeGGs (1). Furthermore, only part of the mixture would be composité molecules. As a consequence, a strong selection was needed. A yeast strain carrying a deletion in the his 4 locus (7) was chosen for transformation since such deletions do not revert, whereby a virtually unlimited selection can be applied. Alleles in this locus are easily classified and identified on the basis of their complementation and recombination patterns.
We describe here the isolation and the genetic characterization of a histidine prototrophic transformant.

\section{MATERIALS AND METHODS}

\subsection{Media and growth}

Complex medium with glucose was YPD (1\% Difco Bacto yeast extract, 2\% Difco Bacto peptone, $2 \%$ glucose). Non-fermentable medium was YPG (as YPD, but with $3 \%$ glycerol instead of glucose). Synthetic minimal medium, SD, was $0.67 \%$ yeast nitrogen base without amino acids (Difco) with glucose (2\%). Synthetic complete medium, SC, was SD supplemented according to ZimmermanN (22). Selective media are designated according to the following examples: SD + leu means SD with the addition of leucine at the concentration used in SC. SC-ade means $\mathrm{SC}$ but with the omission of adenine. Lcanavanine (Sigma) was filter sterilized and used at a concentration of $60 \mathrm{mg} \cdot 1^{-1}$. Plates were solidified with $2 \%$ Difco Bacto agar. Regeneration medium was SD + leu + ade, $1.2 \mathrm{M}$-sorbitol, $3 \%$ Difco Bacto agar. Growth was at $30^{\circ} \mathrm{C}$ and liquid cultures were always grown with aeration.

\subsection{Strains and crosses}

The strains used in this study are shown in Table I. Crosses and tetrad analysis were carried out using standard procedures (10). Crosses involving unstable histidine prototrophic strains were carried out in the absence of histidine. Sporulation was performed on plates of $2 \%$ Difco Bacto agar containing $2 \%$ potassium acetate.

\subsection{Total yeast DNA}

Spheroplasts (16) from $10 \mathrm{~g}$ of cells of A364A $\mathrm{D} 5 \mathrm{U}^{+} \mathrm{A}^{+}$were washed three times and suspended to a volume of $12 \mathrm{ml}$ in SCE (sorbitol citrate EDTA) (16) and added, under stirring, to $100 \mathrm{ml}$ 4.5 M-guanidinium chloride, 0.1 M-EDTA, $0.2 \% \mathrm{~N}$-lauroyl sarcosine (Sigma) adjusted to

Abbreviations: can $=$ L-canavanine, $\mathrm{SC}=$ synthetic complete dextrose, $\mathrm{SCE}=$ sorbitol citrate EDTA, $\mathrm{SD}=$ synthetic minimal dextrose, YPD = yeast extract peptone dextrose, YPG = yeast extract peptone glycerol. 
Table I

Yeast strains used in this study.

\begin{tabular}{|c|c|c|}
\hline Strain & Genotype & Source \\
\hline A364A D5 $\mathrm{U}^{+} \mathrm{A}^{+}$ & Prototrophic diploid & NEWLon et al. (17) \\
\hline A9103A & a his $4-24$ & FINK \& STYLES (7) \\
\hline $\mathrm{A} 9275 \mathrm{C}$ & a his $4-29$ HOLI-I & FINK \& STYLES (7) \\
\hline $322-1 \mathrm{~A}$ & a leul-1 ade $2-1$ & BORAM \& ROMAN (2) \\
\hline $\mathrm{C} 75-\mathrm{M} 23$ & a his $4-24$ ade $2-1$ & Spore from cross A9103A $\times 322-1 \mathrm{~A}$ \\
\hline C75-M26 & a his 4-29 leul-1 & Spore from cross A9275C $\times 322-1 \mathrm{~A}$ \\
\hline III-12 & a his4 -644 ade2 & $\begin{array}{l}\text { Course manual on yeast genetics, Cold Spring } \\
\text { Harbor Laboratory }\end{array}$ \\
\hline IV-1 & $\alpha$ his4 -260 trpl & -- \\
\hline IV-7 & $\alpha$ his $4-260$ ade 2 & -- \\
\hline IV-8 & $\alpha$ his $4-280$ ade 2 & -- \\
\hline IV-11 & a his $4-1155$ ade2 & -- \\
\hline IV -12 & a his4 -864 ade2 & -- \\
\hline KS-I- 15 & a his4-594lysl & T. NilsSON-TillgGREN \\
\hline C76-DI & Prototrophic diploid & $\begin{array}{l}\text { Commercial baker's yeast, } \\
\text { De danske Spritfabrikker, Denmark }\end{array}$ \\
\hline K5-5A & a his $4-15$ ade $2-1$ canl karl -1 & J. CONDE. From a cross of P24 (5) \\
\hline K5-5A[rho-] & $\begin{array}{l}\text { Petite of K5-5A induced } \\
\text { with ethidium bromide }\end{array}$ & \\
\hline $\mathrm{C} 78-\mathrm{H} 26$ & a his4-29[HIS4] leul-1 & Transformant of C75-M26 with ligated DNA \\
\hline $\mathrm{C} 78 \cdot \mathrm{H} 23 / 1$ & a his 4-24[HIS4] ade2-1 & $\begin{array}{l}\text { Transformant of C75-M23 with nucleic acid from } \\
\text { C78-H } 26\end{array}$ \\
\hline C78-I- 12 & a his4[HIS4] trpl & Spore from cross $\mathrm{C} 78-\mathrm{H} 26 \times \mathrm{IV}-1$ \\
\hline C78-I-53 & a his $4[$ HIS4] trpl & -- \\
\hline \multicolumn{3}{|l|}{ Mating type testers: } \\
\hline XXa-II-47 & a leu2 $\operatorname{trp} 5$ & T. NILSSON-TILLGREN \\
\hline XXa-III-4 & a leu2 ade 2.119 & $\ldots$ \\
\hline RS-II-24 & a $|y s|$ & -- \\
\hline RS-II-11 & a lysl & -- \\
\hline
\end{tabular}

pH 8.0 with $\mathrm{NaOH}$. Nucleic acid was precipitated from the lysate with $120 \mathrm{ml} 96 \%$ ethanol for $5 \mathrm{~min}$ and collected by centrifugation for $1 \mathrm{~min}$ in the Sorvall SS-34 rotor at $10,000 \mathrm{rpm}$. It was suspended (only adding droplets at the beginning) in $150 \mathrm{ml}$ of $10 \mathrm{~mm}$-EDTA, $0.5 \mathrm{mg} \cdot \mathrm{ml}^{-1}$ sodium dodecyl sulfate, $0.3 \mathrm{mg} \cdot \mathrm{ml}^{-1}$ pronase (Calbiochem, self-digested at $10 \mathrm{mg} \cdot \mathrm{ml}^{-1}$ in 10 mM-EDTA, pH 8.0 at $37^{\circ} \mathrm{C}$ for 2 hours and heated to $80^{\circ} \mathrm{C}$ for $5 \mathrm{~min}$ ), $\mathrm{pH} 8.0$. After heating for $15 \mathrm{~min}$ to $45^{\circ} \mathrm{C} 10 \mathrm{ml} 2 \mathrm{M}-\mathrm{NaCl}$ were added and the mixture was heated for $15 \mathrm{~min}$ to $60^{\circ} \mathrm{C}$. After cooling to $45^{\circ} \mathrm{C}$ it was treated further with $0.3 \mathrm{mg} \cdot \mathrm{ml}^{-1}$ pronase for $15 \mathrm{~min}$. Then the following steps were carried out according to CRYER et al. (6): Shaking with chloroform/ isoamyl alcohol, one reextraction of the inter- phase and chloroform phase with $50 \mathrm{ml} 50 \mathrm{~mm}$ EDTA pH 8.0, ethanol precipitation of the combined water phases, RNAase treatment, pronase treatment, chloroform/isoamyl alcohol extraction, and ethanol precipitation. The DNA was dissolved and stored frozen in $10 \mathrm{~mm}$ TrisHCl, 10 mм-NaCl, 0.2 mм-EDTA, pH 8.0.

\subsection{Two-micron DNA}

Two-micron DNA was prepared according to LIVINGSTON and KuEIN (14).

\subsection{DNA concentration}

The concentration of DNA in the preparations of sections 2.3 and 2.4 was measured by its 
enhancement (13) of fluorescence of 4,6-diamidino-2-phenylindole (Serva). UV absorbance indicated the presence of some remaining RNA, which was considered unimportant.

\subsection{Nucleic acid for retransformation}

Nucleic acid enriched for plasmid DNA was prepared by precipitation of high molecular weight DNA from a lysate of spheroplasts (12, 15). The nucleic acid in the supernatant was precipitated with ethanol and dissolved in 50 mм-TrisHCl, 10 mм-EDTA, $50 \mathrm{~mm}-\mathrm{NaCl}, 1 \%$ sodium dodecyl sulfate, $\mathrm{pH} 8.0$, containing $1 \mathrm{mg} \cdot \mathrm{ml}^{-1}$ pronase. The solution was incubated for $60 \mathrm{~min}$ at $45^{\circ} \mathrm{C}$, deproteinized with chloroform/isoamyl alcohol and nucleic acid was precipitated with ethanol.

\subsection{Restriction endonuclease treatment and ligation of DNA}

Eight $\mu$ 2-micron DNA from C76-Dl and 16 $\mu \mathrm{g}$ total DNA from A364A D5 $\mathrm{U}^{+} \mathrm{A}^{+}$in 1.1 $\mathrm{ml}$ of $0.1 \mathrm{M}$-TrisHCl, $5 \mathrm{~mm}-\mathrm{MgCl}_{2}, 50 \mathrm{~mm}$ $\mathrm{NaCl}, 10 \mathrm{~mm}$-2-mercaptoethanol, $100 \mu \mathrm{g} \cdot \mathrm{ml}^{-1}$ serum albumin, $\mathrm{pH} 7.4$, were treated with 75 units of restriction endonuclease PstI (Boehringer Mannheim) for 3 hours at $37^{\circ} \mathrm{C}$. The nuclease was inactivated by heating at $65^{\circ} \mathrm{C}$ for $10 \mathrm{~min}$ and after cooling to room temperature $10 \mu \mathrm{l} 0.5 \mathrm{M}$-DL-dithiothreitol and $10 \mu \mathrm{l} 0.1 \mathrm{M}$ ATP were added. Ligation was carried out using 0.2 units of T4 DNA ligase (New England Biolabs) at $12^{\circ} \mathrm{C}$ for 18 hours whereafter DNA was precipitated with $2.8 \mathrm{ml} 96 \%$ ethanol for 1.5 hours at $-80^{\circ} \mathrm{C}$. The DNA was sedimented and dried with a gentle stream of air. It was used for transformation after dissolution in $0.1 \mathrm{ml}$ $1.2 \mathrm{~m}$-sorbitol, $10 \mathrm{~mm}-\mathrm{CaCl}_{2}$.

\subsection{Transformation}

The procedure followed essentially that of BEGGS (1): Spheroplasts were prepared as described, but using $\beta$-glucuronidase/arylsulfatase (Boehringer Mannheim, $0.5 \mathrm{ml}$ per $10^{10}$ cells) to degrade the cell walls. The ligated DNA was mixed with a $0.2 \mathrm{ml}$ suspension of $4 \cdot 10^{8}$ spheroplasts of C75-M26 in $1.2 \mathrm{M}$-sorbitol, 10 $\mathrm{mm}-\mathrm{CaCl}_{2}$. After incubation at $22^{\circ} \mathrm{C}$ for $15 \mathrm{~min}$

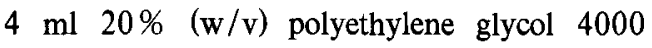
(Merck), $10 \mathrm{~mm}-\mathrm{CaCl}_{2}, 10 \mathrm{~mm}$-TrisHCl, pH 7.5 were added and incubation continued for 20 $\mathrm{min}$. Spheroplasts were sedimented in the SS-34 rotor for $1 \mathrm{~min}$ at $7,000 \mathrm{rpm}$ at $0^{\circ} \mathrm{C}$, suspended in a mixture of $100 \mu \mathrm{ll} 1.2 \mathrm{M}$-sorbitol, $10 \mathrm{~mm}$ $\mathrm{CaCl}_{2}$ and $50 \mu \mathrm{YPD}, 1.2 \mathrm{M}$-sorbitol, $40 \mu \mathrm{g} \cdot \mathrm{ml}^{-1}$ L-leucine, $40 \mu \mathrm{g} \cdot \mathrm{ml}^{-1}$ L-histidine, $40 \mu \mathrm{g} \cdot \mathrm{ml}^{-1}$ adenine sulfate and incubated at $30^{\circ} \mathrm{C}$ for 20 $\mathrm{min}$. They were again sedimented, washed with $5 \mathrm{ml} 1.2 \mathrm{M}$-sorbitol and suspended in $0.45 \mathrm{ml}$ $1.2 \mathrm{~m}$-sorbitol. A volume of $0.3 \mathrm{ml}$ of this suspension was mixed with $7 \mathrm{ml}$ melted regeneration medium at $45^{\circ} \mathrm{C}$ and plated on $\mathrm{SD}+$ leu with $1.2 \mathrm{~m}$-sorbitol.

The procedure for the retransformation experiment differed as follows: The enzyme for making spheroplasts was $\beta$-glucuronidase from Sigma (No. G-0751). After dissolution of the powder, insoluble particles were removed by centrifugation in the SS-34 rotor at $10,000 \mathrm{rpm}$ for $10 \mathrm{~min}$; the enzyme was then used according to BegGs (1). Nucleic acid from C78-H26 (section 2.6, $50 \mu \mathrm{g}$ dissolved in $0.2 \mathrm{ml} 1.2 \mathrm{M}$ sorbitol, $0.5 \mathrm{~mm}$-EDTA) was mixed with $10 \mu \mathrm{l}$ $0.2 \mathrm{M}-\mathrm{CaCl}_{2}$ and $0.2 \mathrm{ml}$ suspension of $2 \cdot 10^{9}$ spheroplasts of C75-M23 in $1.2 \mathrm{M}$-sorbitol and subjected to the procedure described above. Leucine was omitted from the $50 \mu \mathrm{l}$ supplemented YPD and from the regeneration medium and was replaced by adenine in the plates. A serial dilution of DNA treated spheroplasts was made in $1.2 \mathrm{M}$-sorbitol and $0.1 \mathrm{ml}$ portions were plated in $8.5 \mathrm{ml}$ regeneration medium with and without histidine.

\subsection{Induction of recombination with UV}

Plates were irradiated for $5 \mathrm{sec}$ with a Hannovia Letheray Germicidal unit at a distance of $10 \mathrm{~cm}$ and incubated in the dark for 2 days at $30^{\circ} \mathrm{C}$.

\subsection{Filter mating}

Mating for cytoduction was carried out by mixing $0.7 \cdot 10^{7}$ cells of $\mathrm{K} 5-5 \mathrm{~A}$ [rho-] growing exponentially in YPD with $1.4 \cdot 10^{7}$ cells of the other parent growing exponentially in SC-his. The cells were collected on $2 \mathrm{~cm}^{2}$ of a $0.45 \mu$ Millipore filter which was placed on a YPD plate 
for 3 hours and on an SD + ade plate for 6 hours at $30^{\circ} \mathrm{C}$. After 12 hours at $4^{\circ} \mathrm{C}$ a loopful was suspended and diluted in water and $0.1 \mathrm{ml}$ portions were plated on the media indicated.

\subsection{Containment}

Experiments with cells containing recombinant DNA and preparation of recombinant DNA were carried out under Pl conditions (9). The experiments were registered with the committee on genetic engineering of the Danish National Research Councils.

\subsection{Gel electrophoresis of DNA}

Electrophoresis was carried out in $0.7 \%$ agarose (Sigma) in $85 \mathrm{~mm}$-Tris-OH, $89 \mathrm{~mm}$ boric acid, $2.5 \mathrm{mm-Na} 2$-EDTA, $\mathrm{pH} 8.3$ at 5 $\mathrm{V} \cdot \mathrm{cm}^{-1}$ for 5 hours. The gel was stained with ethidium bromide $\left(1 \mu \mathrm{g} \cdot \mathrm{ml}^{-1}\right)$ in the same buffer and photographed under longwave ultraviolet irradiation using a UV- and an orange filter.

\section{RESULTS}

\subsection{Two-micron DNA}

Circular 2-micron DNA from commercial baker's yeast (C76-D1) was treated with restriction endonuclease PstI and subjected to gel electrophoresis in $0.7 \%$ agarose. A single band was seen at the position of 6 kilobases expected for linear whole molecules of 2-micron DNA (Figure 1, lane e). The same result was obtained when restriction endonuclease EcoRI was used (Figure 1, lane d). We conclude that 2-micron DNA from this strain contains one recognition site for PstI and one for EcoRI.

\subsection{Transformation of C75-M26 from his 4 to HIS4}

A mixture of $8 \mu \mathrm{g} 2$-micron DNA from strain C76-D1 and $16 \mu \mathrm{g}$ total DNA from the diploid, prototrophic strain A364A D5 $\mathrm{U}^{+} \mathrm{A}^{+}$was fragmented with restriction endonuclease PstI and then treated with T4 DNA ligase. Transformation of $4 \cdot 10^{8}$ spheroplasts of C75-M26 ( $\alpha$ his4-29 leul-1) with the ligated mixture was carried out as specified in Materials and Methods (section 2.8). The spheroplasts were plated $\left(3 \cdot 10^{8}\right.$

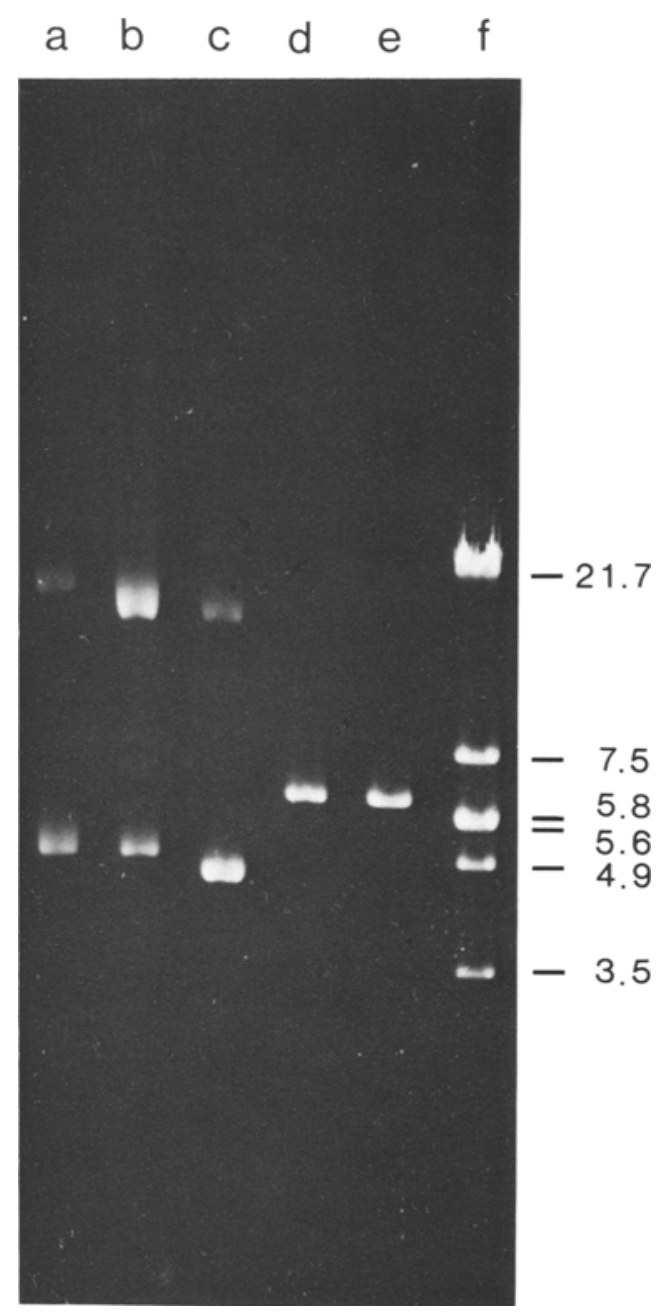

Figure 1. Gel electrophoresis of covalently closed circular DNA from C75-M26 (a), C78-H26 (b) and C76-D1 (c). The upper band is the open circular form and the lower is covalently closed. When about equal amounts of the open circular forms from C75-M26 and $\mathrm{C} 78-\mathrm{H} 26$ are compared, they show the same mobility. Two-micron DNA from C76-D1 (c) has a slightly lower molecular weight than that from the two other strains. Lanes $d$ and e show 2-micron DNA from C76-Dl after treatment with restriction endonucleases EcoRI and PstI, respectively. Lane $f$ is bacteriophage lambda DNA treated with EcoRI for sizing (given in kilobases) of linear DNA.

on one plate) for regeneration. After 3 days at $30^{\circ} \mathrm{C}$ one colony was detected. It was streaked on $\mathrm{SD}+$ leu and a single colony isolated. This presumptive transformant is called $\mathrm{C} 78-\mathrm{H} 26$. 


\subsection{Characterization of $\mathrm{C} 78-\mathrm{H} 26$}

The strain $\mathrm{C} 78-\mathrm{H} 26$ was crossed to mating type tester strains with and without leu2 (see Table I). It was shown that $\mathrm{C} 78-\mathrm{H} 26$ is of mating type $\alpha$ and that is leucine requirement is complemented by LEUI. That C78-H26 carries leul was demonstrated by back crossings to C75-M26 of spore colonies (genotype a [HIS4] leul trpl) from the cross described in Table III. All diploids from these crosses required leucine.

When $\mathrm{C} 78-\mathrm{H} 26$ is grown in histidine containing medium the histidine prototrophy is rapidly lost. After approx. 10 generations in YPD only $3 \%$ of the cells were found to be prototrophs.

Histidine auxotrophic colonies were isolated and we tested which histidine gene was affected. Crosses to strain IV-1 (a his4-260 trpl) gave only histidine auxotrophic diploids. The allele his 4-260 was used since it shows no intragenic complementation (19), and it is clear that the auxotrophic revertants of C78- $\mathrm{H} 26$ are his4. Further crosses with other his 4 tester strains (Table II) showed that the revertants have a complementation and recombination pattern identical to strain C75-M26.

The generation time for C78-H26 in SC-his is approx. 4 hours at $30^{\circ} \mathrm{C}$. In SC the growth rate is higher, giving a doubling time of 2.5 hours. By plating on media with and without histidine, as well as on medium containing a limiting concentration of histidine, it was found that even under selective conditions only $25-30 \%$ of the cells were histidine prototrophs.
In conclusion, strain C78-H26 is indistinguishable from the parental strain C75-M26 except for the unstable histidine prototrophy, and the frequent reversion to histidine auxotrophy uncovers a his 4 allele which seems to be identical to the one in C75-M26.

\subsection{Tetrad analysis of $\mathbf{C 7 8 - H 2 6}$}

To investigate how the histidine prototrophy of C78-H26 is inherited it was crossed to strain IV-1 which carries his4-260. This allele is situated within the deletion in C75-M26; wild type progeny can therefore not be formed by intragenic recombination. Any HIS4 spore from this cross must thus carry the gene for histidine prototrophy from $\mathrm{C} 78-\mathrm{H} 26$ unless reversion of his $4-260$ is considered. To reduce the frequency of histidine auxotrophs all crossing and sporulation procedures were performed in the absence of histidine.

As can be seen in Table III, asci with one or more HIS4 spores are frequent. Twentynine percent of all asci contain at least one prototrophic spore whether germinated on histidine free or histidine containing medium. Several asci with four prototrophic spores were obtained, demonstrating that the gene for histidine prototrophy of $\mathrm{C} 78-\mathrm{H} 26$ is inherited in a nonmendelian way.

Spore colonies from the asci with four histidine prototrophs in Table III were grown to stationary phase in SC-his, plated on YPD and

\section{Table II}

Identification of the his 4 alleles in a revertant of C78-H26 by complementation and UV-induced recombination.

\begin{tabular}{|c|c|c|c|c|c|c|c|c|c|c|c|c|}
\hline \multirow{3}{*}{ Strain } & \multicolumn{12}{|c|}{ Growth on SD after crossing ${ }^{a}$ to } \\
\hline & \multicolumn{2}{|c|}{$\begin{array}{c}\text { IV-12 } \\
\text { (his4-864) }\end{array}$} & \multicolumn{2}{|c|}{$\begin{array}{c}\text { IV-11 } \\
\text { (his4-1155) }\end{array}$} & \multicolumn{2}{|c|}{$\begin{array}{c}\text { IV-8 } \\
\text { (his } 4-280)\end{array}$} & \multicolumn{2}{|c|}{$\begin{array}{l}\text { KS-I-15 } \\
(\text { his } 4-594)\end{array}$} & \multicolumn{2}{|c|}{$\begin{array}{c}\text { III-12 } \\
\text { (his 4-644) }\end{array}$} & \multicolumn{2}{|c|}{$\begin{array}{c}\text { IV-7 } \\
(\text { his } 4-260)\end{array}$} \\
\hline & $-U V$ & $+U V$ & $-U V$ & $+U V$ & $-U V$ & $+U V$ & $-U V$ & $+U V$ & $-U V$ & $+U V$ & $-U V$ & $+U V$ \\
\hline C75-M26 (his4-29) & + & + & - & + & + & + & - & - & - & - & - & - \\
\hline C75-M23 (his4-24) & + & + & - & + & + & + & - & + & - & - & - & + \\
\hline IV-1 (his4-260) & - & + & - & + & - & + & - & + & - & + & - & - \\
\hline K5-5A (his4-15) & + & + & + & + & + & + & + & + & - & - & - & + \\
\hline $\begin{array}{l}\text { Histidine auxotrophic } \\
\text { revertant of } \mathrm{C} 78-\mathrm{H} 26\end{array}$ & + & + & - & + & + & t & - & - & - & - & - & - \\
\hline
\end{tabular}

a) The strains were cross replicated on YPD, incubated for 24 hours, and replicated to SD in duplo. One of the SD plates was UV-irradiated. 
Table III

Tetrad analysis of C78-H26 $\times$ IV-1 (a his4-260 trpl).

\begin{tabular}{ccc}
$\begin{array}{c}\text { No. of histidine } \\
\text { prototrophs per ascus }\end{array}$ & $\begin{array}{c}\text { Dissection and spore germination on } \\
\text { SC-his } \\
\text { no. of asci }\end{array}$ & $\begin{array}{c}\text { YPD } \\
\text { no. of asci a) b) }\end{array}$ \\
\hline 0 & 65 & 10 \\
1 & 4 & 2 \\
2 & 10 & 1 \\
3 & 7 & 0 \\
4 & 5 b) & 1 \\
\hline
\end{tabular}

a) Only tetrads with four viable spores are presented.

b) 2:2 segragation for trpl, leul and mating type was obtained in all cases.

replicated to SC-his. It was found that the instability of the progeny strains did not differ significantly from the parent strain.

\subsection{Cytoduction of the gene for histidine prototrophy}

Cytoduction is a term coined by ZaKHAROV and YAROVOY (21) for the occurrence, after mating, of progeny with the nuclear genotype of one parent and a cytoplasmic marker from the other. An efficient method for cytoduction analysis has been devised by CONDE and FinK (5). It employs the mutation karl-1 which reduces the frequency of karyogamy. If one parent in a cross carries karl-1, most progeny will be cytoductants. A petite of K5-5A ( $\alpha$ his4-15 ade2-1 canl karl-1) was used as recipient in cytoduction. Since $\mathrm{K} 5-5 \mathrm{~A}$ and $\mathrm{C78-}$ H26 have the same mating type, two histidine prototrophic strains of the opposite mating type from the cross described in Table III were used as donors in cytoduction of mitochondrial function, and of the HIS4 gene function. Mating was carried out on filters, placed for 3 hours on a YPD plate followed by 6 hours on an SD + ade plate. The results are shown in Table IV. The high number of red colonies (ade2 [RHO $\left.{ }^{+}\right]$) on YPD shows that mating was efficient; a high proportion of the ade2-1 parent cells became [RHO +]. The two histidine prototrophic parents have an instability comparable to that of C78H26. This is illustrated by the reduction in the number of white colonies on the plates lacking

Table IV

Cytoduction of the HIS4 gene function. Strains C78-I-12 and C78-I-53 (both a trpl his4 [HIS4]) were crossed to K5-5A [rho-] (a his4-15 ade2-I canl karl-I [rho-]).

\begin{tabular}{|c|c|c|c|c|c|c|c|}
\hline \multirow[b]{3}{*}{ Plated on } & \multirow[b]{3}{*}{ Dilution } & \multicolumn{3}{|c|}{$\mathrm{C} 78-\mathrm{I}-12 \times \mathrm{K} 5-5 \mathrm{~A}\left[\mathrm{rho}^{-}\right]$} & \multicolumn{3}{|c|}{ C78-I-53 $\times$ K5-5A $\left[\right.$ rho $\left.^{-}\right]$} \\
\hline & & \multicolumn{3}{|c|}{ no. of colonies per plate } & \multicolumn{3}{|c|}{ no. of colonies per plate } \\
\hline & & red & pink & white & red & pink & white \\
\hline YPD & 5000 & $231^{\mathrm{a})}$ & $251^{b)}$ & $1042^{\mathrm{c})}$ & $590^{\text {a) }}$ & $126^{b)}$ & $900^{c}$ \\
\hline YPG & 5000 & 0 & 0 & 1100 & 0 & 0 & 1332 \\
\hline SC-ade-arg & 5000 & 0 & 0 & 1337 & 0 & 0 & 1296 \\
\hline SC-ade-his-arg & 5000 & 0 & 0 & 497 & 0 & 0 & 389 \\
\hline SC-trp-his-arg + can & 1 & $508^{a)}$ & 0 & 22 & $456^{\mathrm{a})}$ & 0 & 15 \\
\hline
\end{tabular}

a) Genotype ade $2-I\left[\mathrm{RHO}^{+}\right]$

b) Genotype ade $2-1$ [rho-]

c) Genotype $A D E$ 
histidine; many cells have lost the gene for histidine prototrophy during growth. The red colonies on SC-trp-his-arg + can represent the K5-5A[rho-] cells that received the HIS4 gene function in addition to the [ $\left.\mathrm{RHO}^{+}\right]$function. The small number of white colonies on these plates is interpreted as diploid mating products having undergone mitotic recombination for canl resulting in canavanine resistance.

The ratio of cells detected to have received the HIS4 gene function (red colonies on the canavanine containing plates) to cells that received the $\left[\mathrm{RHO}^{+}\right]$function (red colonies on YPD plates) is $4 \cdot 10^{-4}$ and $1.5 \cdot 10^{-4}$ in the two experiments. We take these numbers as an indication for order of magnitude rather than an exact measure of the ratio of transfer of the two functions. For instance, some canl cells may have been phenotypically canavanine sensitive at the time of plating, since they were budded off from heterokaryons containing both canl and $C A N$ nuclei.

From each cross three cytoductant colonies were picked and analysed. They were found to have an unstable prototrophy for histidine and in auxotrophic variants the histidine requirement was found to be due to his4-15 (cf. Table II) as tested by complementation and UV-induced recombination.

\subsection{Treatment of strain $\mathrm{C} 78-\mathrm{H} 26$ with ethi- dium bromide}

From the tetrad analysis it emerges that the histidine prototrophy of strain $\mathrm{C} 78-\mathrm{H} 26$ is, like mitochondrial DNA, extrachromosomally inherited. Ethidium bromide is known to produce a high frequency of petites (respiratory deficient strains) caused by great alterations in, or complete loss of, mitochondrial DNA (3). To investigate the effect of ethidium bromide on the histidine prototrophy, strain $\mathrm{C} 78-\mathrm{H} 26$ was treated with ethidium bromide $\left(10 \mu \mathrm{g} \cdot \mathrm{ml}^{-1}\right)$ for 24 hours. The cells were plated on YPD and the colonies were replicated to a non-fermentable substrate (YPG) and a medium lacking histidine.

As can be seen in Table $V$, control and ethidium bromide treated cells show the same frequencies of histidine prototrophy, although $98 \%$ of the treated cells had become petites. Furthermore, the frequencies of spontaneous as well as induced petites were about the same in the total population as among the histidine prototrophic cells, i.e. no correlation was seen between the loss of the gene for histidine prototrophy and the loss of [RHO ${ }^{+}$.

\subsection{Retransformation}

Nucleic acid from C78-H26 and C75-M26 was prepared as described in section 2.6. Spheroplasts of C75-M23 ( $\alpha$ his 4-24 ade2-l) were treated with these nucleic acid preparations (section 2.8). Four percent of the plated spheroplasts gave rise to colonies in the presence of histidine. When spheroplasts treated with nucleic acid from $\mathrm{C} 78-\mathrm{H} 26$ were plated on medium lacking histidine, 3 colonies appeared after 3-4 days at $30^{\circ} \mathrm{C}$. No colonies were obtained in controls where spheroplasts were mixed with

\section{Table V}

Treatment of $\mathrm{C78}-\mathrm{H} 26$ with ethidium bromide. Approx. $10^{7}$ cells $\cdot \mathrm{ml}^{-1}$ were shaken in $\mathrm{SC}$-his containing ethidium bromide $\left(10 \mu \mathrm{g} \cdot \mathrm{ml}^{-1}\right)$ for 24 hours in the dark at $25^{\circ} \mathrm{C}$.

\begin{tabular}{|c|c|c|c|c|c|}
\hline & \multicolumn{3}{|c|}{ Plated on YPD } & \multicolumn{2}{|c|}{ Plated on SC-his } \\
\hline & $\begin{array}{l}\text { no. of } \\
\text { colonies }\end{array}$ & $\begin{array}{c}\text { petites }^{\mathrm{a})} \\
\%\end{array}$ & $\begin{array}{c}\text { histidine }^{\text {b) }} \\
\text { prototrophs } \\
\%\end{array}$ & $\begin{array}{c}\text { no. of } \\
\text { colonies }\end{array}$ & $\begin{array}{c}\text { petites }^{\mathrm{a})} \\
\%\end{array}$ \\
\hline Non-treated & 1040 & 11.3 & 33.3 & 408 & 12.0 \\
\hline $\begin{array}{l}\text { Treated with } \\
\text { ethidium bromide }\end{array}$ & 1300 & 98.8 & 35.3 & 438 & 98.0 \\
\hline
\end{tabular}

a) Determined by replication to YPG.

b) Determined by replication to SC-his. 
either nucleic acid from C75-M26 or buffer without any nucleic acid. Putative transformants were isolated on medium lacking histidine. One of these, called C78-H23/1, was further analysed.

Strain C78-H23/1 proved by growth in medium without histidine and subsequent plating on medium with limiting amounts of histidine to resemble strain $\mathrm{C} 78-\mathrm{H} 26$ in its instability for histidine prototrophy. In all other respects (mating type, adenine requirement and degree of flocculence) it closely resembled strain C75-M23. By complementation tests like those described in Table II, it could be shown that the histidine requiring revertants of $\mathrm{C} 78-\mathrm{H} 23 / 1$ carry a his 4 allele which gives a complementation and recombination pattern identical to his4-24 (cf. Table II).

To analyse the inheritance of the histidine prototrophy, C78- $\mathrm{H} 23 / 1$ was crossed to IV-1 and the diploid sporulated in the absence of histidine. Spore viability was low in asci from this diploid. Asci with three, two, one or no histidine independent spores were found, proving the non-mendelian inheritance of the histidine prototrophy also in this case. No tetrads with four histidine prototrophic spores were found. Prototrophic progeny colonies were again tested for the stability of the HIS character as described for C78-H26. Except for one strain, all proved to be as unstable as the parent $\mathrm{C} 78$ $\mathrm{H} 23 / 1$. In the exceptional strain $97 \%$ of the cells were found to retain their histidine independence even after prolonged growth in YPD.

\subsection{Gel electrophoresis of covalently closed circular DNA from strain C78-H26}

Covalently closed circular DNA was extracted from strains C78-H26 and C75-M26 according to Livingston and KLEIN (14) and analysed by gel electrophoresis (Figure 1). The two preparations appeared to be similar.

\section{DISCUSSION}

Using a total amount of $24 \mu \mathrm{g}$ of DNA and $4 \cdot 10^{8}$ spheroplasts we have obtained one transformant. A rough estimation based upon the transformation frequency obtained by BEGGs (1) indicates that optimal ligation, a higher concen- tration of spheroplasts and an optimal regeneration frequency could give 10-100 transformants with this amount of DNA. Since ligation and regeneration were not monitored, it is possible that our transformation frequency can be improved.

Tetrad analysis (Table III) demonstrates that the gene for histidine prototrophy in the transformant $\mathrm{C} 78-\mathrm{H} 26$ is not stably associated with any chromosome. Our interpretation is that the gene for histidine prototrophy is situated on an autonomously replicating unit, although a simultaneous unstable chromosomal association has not been excluded. It remains to be shown whether this unit contains 2-micron DNA. Nonmendelian inheritance has also been characteristic for the chimaeric plasmids containing a bacterial plasmid, 2-micron DNA and the yeast LEU2 gene (1).

The transformant, as well as its meiotic histidine prototrophic progeny, turned out to be very unstable. For maintenance of the histidine independence it was necessary to culture the strains on histidine free medium. Even under these selective conditions only $25-30 \%$ of the cells were histidine prototrophic. The addition of histidine resulted in a rapid drop in the frequency of prototrophic cells. Although other possibilities exist, we find it likely that the occurrence of the histidine auxotrophic cells is due to inefficient replication of the gene for prototrophy, resulting in a low copy number and daughter cells without the gene. This is consistent with an electrophoretic analysis (Figure 1) of covalently closed circular DNA from the transformants and their parent strains; no other species than 2-micron DNA was seen after staining with ethidium bromide. Experiments are in progress to detect and characterize the DNA which contains the gene for histidine prototrophy by molecular hybridization.

The location of the gene in the cell is unknown. The finding that it can be transferred in cytoduction might indicate a cytoplasmic location. But it could also be argued that the observed low frequency of transfer results from a preferred location of the gene in the nucleus interrupted by infrequent periods of a cytoplasmic location.

A treatment with ethidium bromide which induced an extensive number of petites did not 
cause any observable change in the frequency of histidine prototrophic cells in a culture of C78H26. Neither the spontaneous nor the induced loss of the grande character correlated with the loss of the gene for histidine prototrophy. It is therefore not likely that the transformation to histidine independence is associated with mitochondrial DNA. Furthermore, the experiment showed that the gene for histidine prototrophy, like 2-micron DNA $(4,8)$, is not grossly affected by ethidium bromide treatment.

From the cross C78-H23/1 $\times$ IV-1 one exceptional strain was obtained with a higher stability than that of C78-H23/1. The fact that it was not completely stable excludes simple explanations like intragenic recombination between his4-24 and his4-260. There are two obvious possibilities for the nature of this strain. The copy number for the autonomously replicating unit carrying the gene for histidine prototrophy may be increased, or the unit may be integrated in the chromosome. Further properties of this strain will be reported in a subsequent publication.

The retransforming activity of nucleic acid from $\mathrm{C} 78-\mathrm{H} 26$ indicates that the autonomously replicating unit can be obtained and purified, so that other fragments of DNA can be inserted in vitro. At the present stage, however, the presumed low copy number is a serious obstacle to such operations. The instability of the transformants, and the necessity of using his 4 strains as receptors, present other limitations for the use of the described system as a transformation vector system in yeast. The appearance of semi-stable variants may be a solution to overcome some of these obstacles.

\section{ACKNOWLEDGEMENTS}

The excellent technical assistance of JANNE V. HANSEN and BARBARA WILKEN is greatly appreciated. We thank JAIME CONDE for the strain carrying the kar mutation, Professor DITER VON WETTSTEIN for critical reading of the manuscript, and Professor EBBa Lund for advice concerning containment. Financial support to Professor Diter voN WetTSTEIN by grant 511-10006, 512-10005, 516-10004 from the Danish National Research Councils is gratefully acknowledged.

\section{Note added in proof:}

Instability of yeast transformants containing a chimaeric plasmid consisting of 2-micron DNA sequences, the E.coli plasmid pBR322 and a yeast chromosomal segment including the HIS3 gene has been published by STRUHL et al.: Proc. Natl. Acad. Sci. U.S. 76, 1035-1039 (1979) after the submission of this paper.

\section{REFERENCES}

1. BEGGS, J. D.: Transformation of yeast by a replicating hybrid plasmid. Nature 275, 104109 (1978)

2. Boram, W. R. \& H. Roman: Recombination in Saccharomyces cerevisiae: A DNA repair mutation associated with elevated mitotic gene conversion. Proc. Natl. Acad. Sci. U.S. 73, 2828 2832 (1976)

3. Borst, P.: Mitochondrial nuclei acids. Ann. Rev. Biochem. 41, 333-376 (1972)

4. Clark-Walker, G. D.: Isolation of circular DNA from a mitochondrial fraction from yeast. Proc. Natl. Acad. Sci. U.S. 69, 388-392 (1972)

5. Conde, J. \& G. R. Fink: A mutant of Saccharomyces cerevisiae defective for nuclear fusion. Proc. Natl. Acad. Sci. U.S. 73, 36513655 (1976)

6. Cryer, D. R., R. Eccleshall \& J. Marmur: Isolation of yeast DNA. Meth. Cell Biol. 12 , 39-44 (1975)

7. Fink, G. R. \& C. A. Styles. Gene conversion of deletions in the HIS4 region of yeast. Genetics 77, 231-244 (1974)

8. Griffiths D. E., W. E. Lancashire \& E. D. ZANDERS: Evidence for an extra-chromosomal element involved in mitochondrial function: A mitochondrial episome? FEBS Lett. 53, 126130 (1975)

9. Guidelines for Research Involving Recombinant DNA Molecules. Federal Register U.S., 22 DEC 1978, pp. 60108-60131

10. Hawthorne, D. C. \& R. K. Mortimer: Chromosome mapping in Saccharomyces: Centromere-linked genes. Genetics 45, 1085-1110 (1960)

11. Hinnen, A., J. B. Hicks \& G. R. Fink: Transformation of yeast. Proc. Natl. Acad. Sci. U.S. 75, 1929-1933 (1978)

12. HIRT, B.: Selective extraction of polyoma DNA from infected mouse cell cultures. J. Mol. Biol. 26, 365-369 (1967)

13. Kapuścíśski, J. \& B. Skoczylas: Simple and rapid fluorimetric method for DNA microassay. Anal. Biochem. 83, 252-257 (1977) 
14. Livingston, D. M. \& H. L. Klein: Deoxyribonucleic acid sequence organization of a yeast plasmid. J. Bacteriol. 129, 472-481 (1977)

15. Livingston, D. M. \& D. M. Kupfer: Control of Saccharomyces cerevisiae $2 \mu \mathrm{m}$ DNA replication by cell division cycle genes that control nuclear DNA replication. J. Mol. Biol. 116, 249-260 (1977)

16. Newlon, C. S. \& W. L. Fangman: Mitochondrial DNA synthesis in cell cycle mutants of Saccharomyces cerevisiae. Cell 5, 423-428 (1975)

17. Newlon, C. S., T. D. Petes, L. M. Hereford \& W. L. Fangman: Replication of yeast chromosomal DNA. Nature 247, 32-35 (1974)

18. Ratzkin, B. \& J. Carbon: Functional expression of cloned yeast DNA in Escherichia coli. Proç. Natl. Acad. Sci. U.S. 74, 487-491 (1977)
19. Shaffer, B., J. Rytka \& G. R. Fink: Nonsense mutations affecting the HIS4 enzyme complex of yeast. Proc. Nat1. Acad. Sci. U.S., 63, 11981205 (1969)

20. Sinclair, J. H., B. J. Stevens, P. Sanghavi \& M. RABINOWITZ: Mitochondrial-satellite and circular DNA filaments in yeast. Science 156 , 1234-1237 (1967)

21. Zakharov, I. A. \& B. Ph. Yarovoy: Cytoduction as a new tool in studying the cytoplasmic heredity in yeast. Mol. Cellul. Biochem. 14, 1518 (1977)

22. Zimmermann, F. K.: Detection of genetically active chemicals using various yeast systems. In: Chemical Mutagens. Principles and Methods for their Detection. A. Hollaender ed., Plenum Press. New York - London, Vol. III pp. 209239 (1973) 